\title{
Die Christelike etiek en die vraag na 'n Bybels-geregverdigde ekonomiese stelsel
}

\author{
DJ SMITH
}

Die kerk wil en moet in sy etiese uitsprake ' $n$ uitspraak maak oor wat die regte Christelike opvatting oor besitreg en die gebruik van ons eiendom is - dus ook ' $n$ uitspraak oor privaatbesit. Hierdie uitsprake word dikwels gemaak aan die hand van 'n uitleg van die agste gebod. Dit is egter ook 'n onontkombare feit dat daar ook vanuit die wêreld van ekonomiese werklikhede om ons vanuit verskillende ekonomiese stelsels uitsprake gemaak word oor die privaatbesit van die mens, en dat hierdie opvattings oor privaatbesit dikwels as ' $n$ ideologie aan die mens voorgehou word. Die kerk word deur hierdie feitelike stand van sake gedwing om van die aansprake van die ekonomiese stelsels oor privaatbesit kennis te neem en self verantwoording te gee van sy eie standpunt oor privaatbesit en ook oor die verskillende ekonomiese stelsels.

Die vroeëre verloop van die geskiedenis was sodanig dat die vraag na privaatbesit en die vraag na die geskikte ekonomiese sisteem nie op die voorgrond getree het nie. Dit is eers die Industriële Revolusie in die vorige eeu en sy nadraai wat hierdie vrae en ook ander ekonomiese vrae skerp na die voorgrond gebring het. ' $n$ Paar van die kenmerke van die Industriële Revolusie wat hiertoe aanleiding gegee het was die volgende: Handearbeid en daarmee saam baie ou tuisbeoefende ambagte het al hoe meer in onbruik geraak. Die hele gemeenskap is uit 'n tuisbedryf en bestaansekonomie geruk en op kapitalistiese grondslag van loon en arbeid gevorm. Die aandeel van die masjien aan die ekonomiese proses het ten koste van die menslike arbeider toegeneem. Hierdie hele omwenteling het nuwe organisasie-metodes en indelings op persoonlike sowel as sakegebied (ekonomiese gebied) vereis. Die hele ontwikkelingsgang van die Industriële Revolusie het daartoe gelei dat die eiendomsvraagstuk, die saak van privaatbesit, die vraag na die regte verdeling van eiendom en rykdom en die beste ekonomiese stelsel om dit moontlik te maak, sterk na vore gekom het.

Die geskiedenis het tot in ons dag so verloop dat daar uiteindelik vier hoofmoontlikhede voorgehou is as die ekonomiese sisteem wat die vraagstuk van eiendom en privaatbesit die beste kan oplos. Die antwoorde wat gegee is, gaan in die reël uit van 'n onderskeid tussen verbruiks- en produksiegoedere. Wat verbruiksgoedere betref het dit geblyk dat 'n reg op die besit van gebruiksgoedere ' $n$ 
enkeling kwalik ontsê kan word. Op die vlak is een of ander vorm van eiendomsreg byna vanselfsprekend. Waar dit egter op die reg van besit van produksiegoedere neerkom, het die meninge skerp uiteengegaan. Aan die een kant is gehandhaaf dat die individu ook die reg op die besit van produksiegoedere het. Aan die ander kant is die standpunt ingeneem dat die produksiegoedere (grond, kapitaal, fabrieke, ens.) aan almal gesamentlik behoort. In 'n radikale vorm is daar ook die standpunt ingeneem dat nie alleen die produksiegoedere gemeenskaplike besit van almal is nie, maar dat dit ook so is dat een of ander sosiale grootheid die eintlike besitter en verdeler van die verbruiksgoedere is (dus geen privaatbesit hoegenaamd nie).

Die vier hoofmoontlikhede wat voorgehou word as 'n ekonomiese oplossing vir dié reëling van die eiendomsvraagstuk is dan:

1. Radikale privaatbesit (Kapitalisme) waar sowel verbruiksgoedere as produksiegoedere volledig in besit van die enkeling is en die staat slegs moet toesien dat niemand se eiendomsreg aangetas word of eiendom onwettig verkry word nie.

2. Radikale Kommunisme waar die besitreg van sowel verbruiksgoedere en produksiegoedere aan almal gesamentlik behoort en die enkeling net reg het op die gebruik van sekere verbruiksgoedere met die staat as uitdeler van die verbruiksgoedere.

3. Sosialisme waar verbruiksgoedere onder bepaalde reëls aan privaatbesit oorgelaat, word terwyl die produksiegoedere, die beskikking daaroor en die uitdeel daarvan aan die gemeenskap as geheel toekom.

4. Die sosiaal-geïnteresseerde staat wat privaatbesit van sowel verbruiks- asook produksiegoedere toelaat, maar homself die reg toeëien om in mindere of meerdere mate in te gryp in die privaateiendomsreg van die individu ten gunste van die belang van die gemeenskap as geheel. $\mathrm{Na}$ my mening het ons tans in Suid-Afrika 'n ekonomiese stelsel wat baie elemente van hierdie stelsel het.

Die stand van sake soos ons dit tot hiertoe geskilder het dwing die kerk om 'n uitspraak te maak oor besitreg van die individu, die regverdige verdeling van eiendom en rykdom en ook oor die antwoord wat die verskillende ekonomiese stelsels hierop gee. Beantwoord die oplossing van ' $n$ besondere ekonomiese stelsel aan die Christelike opvatting van reg en geregtigheid en naasteliefde? Ons kan die saak ook so stel: Watter standpunt moet die kerk inneem in sy etiese uitsprake oor die sake en die toepassing daarvan op die oplossings wat die onderskeie ekonomiese stelsels voorhou? Aan die begin van die opkoms van die marxistiese Sosialisme was die me- 
ning in sommige kerklike kringe dat die kerk se antwoord die sogenaamde "Social Gospel" moet wees. Hieroor wil ons egter nie nou paat nie.

Haitjema wys in sy boek oor die Heidelbergse Kategismus daarop dat ons by die uitleg en toepassing van die agste gebod veral na twee kante gevaar loop om te ontspoor. Aan die een kant kan ons van 'n radikale teenstelling tussen geregtigheid (ook sosiale geregtigheid op ekonomiese terrein) en liefde uitgaan, soos Brunner in sy boek "Gerechtigkeit". Aan die ander kant loop ons ook die gevaar om die gebod te glad en reëlreg tot grondslag te maak vir aanwysinge op die terrein van sosiaal ekonomiese vraagstukke (hy noem die voorbeeld van Bolkestein in sy boekie oor die tien gebooie).

Brunner is van oordeel dat die agste gebod niks sê oor die lig- en skaduweekante van privaatbesit nie, maar dat die gebod alleen diefstal veroordeel sonder om vas te stel wat regmatige en onregmatige eiendom is, of wat wettige en onwettige wins is (S 122). Volgens hom is daar ' $n$ teenstelling tussen sosiale geregtigheid en die liefde tot die naaste soos wat dit o.a. in hierdie gebod geëis word. Die liefde wat God eis kan wel met sosiale geregtigheid rekening hou, maar is nie daaraan gelyk nie.

Die ander gevaar is dat die gebod te glad en maklik van toepassing gemaak word op sosiaal ekonomiese gebied, so asof die gebod ' $n$ rigtingwyser kan wees na die ideale ekonomiese sisteem. Veral na die Tweede Wêreldoorlog is die gebod dikwels so uitgelê dat dit toegepas is in die rigting van Sosialisme. Daar is te maklik gevoelvolle pleidooie gelewer waarin 'n gemeenskaplike besit van kapitaalgoedere bepleit word, om dan daarna eenvoudig te verklaar dat die praktiese uitwerk van die vraagstukke aan ekonome en politici oorgelaat moet word. In die waas van sosialistiese idealisme word nie daarmee rekening gehou dat dit in der waarheid hier om baie ingewikkelde vraagstukke gaan nie.

Selfs nugtere Lutherse en Calvinistiese etici soos NH Sфe (S 247) en Walter Kreck (veral vanaf S 251) toon in 'n mindere of meerdere mate sekere sentimente ten gunste van sekere aspekte van die sosialistiese en kommunistiese ekonomiese stelsels. Beide die genoemde etici erken dat die Christelike Etiek nie met 'n pasklaar antwoord op ekonomiese gebied kan kom nie en nie in staat is om 'n vaste ekonomiese program op te stel wat vir alle tye geld nie. Tog is byvoorbeeld S $\phi$ e van mening dat die Kommunisme nader staan aan die Christelike begrip van ekonomiese en sosiale geregtigheid as die Kapitalisme omdat dié in sy wese onchristelik sou wees. Hy maak die stelling ewenwel met die byvoeging dat 'n Christen wel nie vir Kommunisme in sy ekstreme vorm kan kies nie. Sy ideaal lê blykbaar in een of ander vorm van gematigde Sosialisme. In alle bil- 
likheid moet gesê word dat sowel Sфe as Kreck in alle ander opsigte ' $n$ baie nugtere beoordeling van hierdie saak het.

In die kringe waar die sosialistiese ideaal as die Christelike voorgehou word, speel verwysinge na die vrywillige gemeenskap van goedere onder die eerste Christene, soos verhaal in Hand 2 vers 44 vv. en 4 vers 32 vv., ' $n$ belangrike rol. Tog is dit duidelik dat ons nie hier met ' $n$ gedwonge sosiale maatreël wat vir alle tye moes geld, te doen het nie. Dit is ook duidelik dat ons selfs nie eers kan aanneem dat almal letterlik alles verkoop en verdeel het nie. Die veronderstelling is dat daar wel ' $n$ privaatbesit is, waaruit bydraes tot die gemeenskaplike kas gemaak kon word, daarom is byvoorbeeld Barnabas se groot offerbereidheid in Hand 4:36 en 37 as vermeldingswaardig geag. Die geskiedenis van Ananias en Saffira in Hand 5 vers 1 tot 11 toon ook duidelik aan dat dit 'n geheel vrywillige saak was. Elkeen het volle sê oor sy eie eiendom behou waaroor hy kon beskik soos hy wou. Sy bydrae is geheel en al vrywillig. In der waarheid het ons in hierdie geskiedenis te doen met 'n spontane uiting van die onderlinge liefde in Christus met die oog op die groot nood wat daar in die jong gemeente geheers het. Ons het hier geensins te doene met'n gedwonge stelsel wat van die gedagte uitgaan dat privaatbesit 'n mens ontneem moet word nie; inteendeel, word 'n privaatbesit veronderstel waaruit groot vrywillige offers vir die gemeenskaplike belang van die gemeente gemaak kan word omdat die liefde in Christus daartoe dwing.

Wat sê die res van die Bybel oor die saak? Is dit werklik so dat die Christelike liefde dring tot die ideaal van eiendomsgemeenskap en privaatbesit tot sonde maak? Dit blyk dat die Ou Testament in elke geval baie positief is wat privaatbesit betref. Rykdom is as 'n seën van die Here beskou. Tog staan die Ou Testament nie op die standpunt van die Romeinse Reg, nl. van die ius et abutendi nie. Dit word aanvaar dat die land met al sy eiendomme ten diepste ' $n$ erfenis van die Here is en daarom nie misbruik mag word tot nadeel van ander volksgenote nie. Inteendeel, die armes mag nie gebrek ly nie, maar moet deur die rykes versorg word. (Vgl. die bepalings van die Sabbatjaar en Jubeljaar in Lev 25, en die kwytskelding van skuldenaars elke sewe jaar in Deut 15 vers $1 \mathrm{vv}$.).

In die Nuwe Testament waarsku Jesus wel sterk teen die gevare van rykdom (vgl. Matt 6 vers 24 en Matt 19 vers 16 vv.). Tog het Jesus nie van sy dissipels geëis om van hulle eiendom af te sien nie. So het Petrus ' $n$ huis in Kapernaüm besit (Matt 8 vers 14) en volgens Luk 8 vers 3 was daar vrouens wat genoeg besittings gehad het om Jesus daarmee te dien. Dit blyk in elk geval dat ons uit Jesus se uitsprake geen uitsprake kan maak met betrekking tot voorskrifte vir'n ekonomiese sisteem nie.

Ook in die uitsprake van Paulus vind ons geen eis om af te sien 
van die besit van eiendom nie. Hy eis slegs mededeelsaamheid by die liefdesmaaltye en die bereidheid om met ons besittings in die gemeente te dien namate 'n mens stoflik geseën word, soos byvoorbeeld by die insameling vir die gemeente in Jerusalem (II Kor 8 en 9). Ons moet wel vergenoegd lewe en bewus wees van die gevare van rykdom ( 1 Tim 6 verse 6 tot 11), want gierigheid is afgodery (Kol 3 vers 5). In werklikheid maak dit nie saak of ons baie of min besit nie, maar wel dat ons vergenoegd sal wees met wat ons het (Fil 4 veis 11 v.).

In die Jakobusbrief kies Jakobus die kant van die armes in 'n gemeente waarin sterk sosiale onderskeide geheers het. Tog wys hy nie die besit van eiendom af nie. Ook hier word dit duidelik - ons vind in die Bybel geen voorskrif met betrekking tot ' $n$ ekonomiese stelsel nie, maar wel dat ons deur die liefde van Christus en die Christelike barmhartigheid gelei sal word waar ons besittings die lewe van ons naaste raak.

Ons kan hier ook nog ingaan op die houding wat die kerk in verskillende tye in die loop van die kerkgeskiedenis ten opsigte van die eiendomsvraag ingencem het, maar wil slegs verwys na Sфe (S. 240-243) vir 'n kort opsomming van die saak.

Indien ons enigsins onbevooroordeeld is, behoort dit duidelik te wees dat ons nie sonder meer vanuit die Bybelse getuienis en vanuit die agste gebod reëlreg riglyne kan trek vir die opbou van 'n ekonomiese stelsel nie. Die saak van die ekonomiese lewe van die mens is hiervoor heeltemal te ingewikkeld en daarby is die Bybel geen wetenskaplike handboek vir die ekonomie waarvolgens 'n sosiaal-ekonomiese program opgestel kan word nie. Daar is ook nog heeltemal te veel begripsonduidelikheid in die argumente rondom die saak. Ons vind byvoorbeeld dat die begrip geregtigheid met die begrip Christelike liefde verbind word in die argumente rondom ekonomiese en sosiale geregtigheid. Die gedagte is dan dat die Christelike liefde inhoud moet gee aan die begrip van ware geregtigheid, maar dan blyk dit dat die begrip Christelike liefde nie altyd suiwer verstaan word en byvoorbeeld humanisties of sentimenteel (gevoelsmatig) gekleur word. Of die begrip liefde word ook tot 'n kapstok vir die eie ideologiese oortuiging gemaak.

Ook wat die begrip "geregtigheid" betref, is dit duidelik dat dit tot dusver onmoontlik was om ' $n$ heldere begrip van "geregtigheid" te laat uitkristalliseer sover dit die gemeenskap en menslike lewe in al sy uitinge betref. Te dikwels word die begrip geregtigheid inhoud gegee vanuit 'n sekere politieke of ideologiese standpunt.

Dit is, onses insiens, 'n nugtere oordeel om te stel dat die Christelike Etiek geen sosiaal-ekonomiese program kan opstel of mag probeer opstel wat vir alle tye geld nie. Wat ons wel kan doen is om die eis van God se Woord met betrekking tot ons besit en die verdeling 
van eiendom te stel binne die ekonomiese stelsel waarin ons ons bevind om daar hervormend in te werk op o.a. die wetgewing in dié verband.

A. de Quervain het die saak baie duidelik gestel waar hy sê (die Heiligung, S $451 \mathrm{ff}$.) dat die agste gebod 'n getuienis is van die heerskappy van God in Christus met betrekking tot die gawe van naaste. Die gebod staan nie in diens van 'n bepaalde gemeenskapsordening nie. Die agste gebod is die beveiligende beskerming van die arme en geld vir elke maatskaplike stelsel, vir elke eiendomsbegrip. Selfs in die beste ekonomies-maatskaplike stelsel sal daar altyd armes en verdruktes wees en daarom ook die gevaar dat ons die eis van God se gebod met betrekking tot ons naaste en sy nood sal verontagsaam, daarom moet die eis van God se gebod binne elke maatskaplike stelsel gestel word.

Geen sosiaal-ekonomiese struktuur wat deur mense bedink is, kan volmaak wees nie. Die gebod sal geldend gemaak moet word binne watter stelsel ons ons ook al bevind. Dáár binne die ekonomiese stelsel sal die Christen altyd vanuit die agste gebod die eis moet stel dat rykdom en welvaart aangewend moet word vir die diens van die naaste. Die besef moet steeds in die hart leef: wat ek het, het ek nie vir myself nie, maar vir myself en die ander. Besittings is daar om die naaste en die samelewing reg en ten beste te dien.

Diegene binne die Christelike kerk wat so maklik aan een of ander sosiaal-ekonomiese stelsel sanksie wil gee vanuit die Bybel, word nie net deur bostaande teologies-etiese stellinge tot versigtigheid gemaan nie, maar kan ook gerus aandag gee aan die waarskuwing van die ekonoom JA Lombard: "'n Ekonomiese stelsel is altyd in wording langs bogenoemde dinamiese proses van optrede: ex post evaluering, en reaksie en ex ante vooruitbeplanning, uitvoering en optrede waarna weer ex post evaluering volg. Dit is moontlik om aan hierdie proses transendentale betekenis te gee soos die filosowe en teoloë dikwels doen, maar selfs 'n goeie teoloog of filosoof sou sy wenkbroue optrek as die sisteem, soos dit op 'n bepaalde oomblik in die dinamiese proses van wording, daar uitsien, opgeteken word as 'n staties ewige formule wat in al sy operatiewe dimensies net so oorgeplaas kan word op enige ander gemeenskap in ' $n$ ander stadium van wording." (In die referaat Die ekonomiese stelsel van SowjetRusland in die bundel onder redaksie van prof G Cronje: Kommunisme - Teorie en Praktyk. JL van Schaik Beperk, Pretoria, 1969 bl. 55).

\section{Literatuurverwysings}

Bolkestein, MH s.a. De tien geboden. Amsterdam.

Brunner, E 1943. Gerechtigkeit. Eine Lehre von den Grundgezetzen der Gesellschaftsordnung. Zürich.

Engelbrecht, BJ s.a. Die wet van God. Pretoria. 
Haitjema, Th L 1962. De Heidelbergse Catechismus als klankbodem en inhoud van het actuele belyden onzer Kerk. Wageningen.

Kreck, W 1975. Grundfragen christlicher Ethik. München.

Lombard, JA 1969. Die ekonomiese stelsel van Sowjet-Rusland, in Cronje, G 1969. Kommunisme - Teorie en praktyk. Pretoria.

Quervain, A de 1946. Die Heiligung-Ethik erster Teil. Zürich.

Sode, NH 1965. Christliche Ethik. Ein Lehrbuch. 3. Auflage. München.

Wurth, G Brillenburgh 1959. Christelijke Zedenleer. Groningen. 